\title{
Rare Interstitial Pneumonia Due to the Use of Aripiprazol: A Case Report
}

\section{Aripiprazol Kullanımına Bağlı Nadir Görülen Interstisyel Pnömoni: Olgu Sunumu}

Gulistan Alpagat, Ayse Baccioglu, Sumeyra Alan Yalim, Merve Poyraz, Betul Dumanoglu, Ayse Fusun Kalpaklioglu

\section{Abstract}

It is accepted that 2-3\% of interstitial lung diseases (ILD) are due to drugs, and that $70 \%$ of drug-induced lung diseases are due to ILD. We present here the case of a 51 -year-old female patient who had been taking aripiprazole for bipolar disorder for 3 years and had been undergoing asthma treatment for 2 years. ILD was considered based on the patient's clinic, a restrictive pattern in the pulmonary function test (PFT), a decreased carbon monoxide diffusion test, laboratory results, radiological findings and biopsy. The possible etiologies of infection, aspiration, heart failure, pet feeding status and exposure to hazardous respiratory substances were excluded. The suspected drug was discontinued and oral corticosteroid treatment was started. Lung toxicity can develop with drug treatments, and so drug history should be questioned in detail and discontinued immediately in case of any doubt. ILD is rare, and if the drug is not suspected and continued, the disease may become chronic and progress to respiratory failure. We present this case to increase awareness of the disease.

Key words: Interstitial Lung Disease, aripiprazole, interstitial pneumonitis, steroid treatment.

\section{Özet}

İnterstisyel akciğer hastalıklarının (IAH) \%2-3'unun ilaçlara bağlı olduğu ve ilaca bağlı akciğer hastalıklarının \%70'inin IAH'dan olduğu kabul edilmektedir. Elli bir yaşında kadın hasta 3 yıldır bipolar bozukluk için aripiprazol kullanmakta ve 2 yıldır astım tedavisi görmekteydi. Hastanın kliniği, solunum fonksiyon testinde (SFT) restriktif patern olması, azalmış karbon monoksit difüzyon testi, laboratuvar sonuçları, radyolojik bulguları ve biyopsi ile IAH düşünüldü. Olası etiyolojiler: enfeksiyon, aspirasyon, kalp yetmezliği, evcil hayvan besleme durumu, tehlikeli solunum maddelerine maruziyet dışlandı. Şüpheli ilaç kesilerek, oral kortikosteroid tedavisi başlandı. Ilaç tedavileri ile akciğer toksisitesi gelişebilir. İlaç öyküsü ayrıntılı olarak sorgulanmalı ve şüphe durumunda derhal kesilmelidir. IAH nadir görülür; ilaçtan şüphelenilmez de devam edilirse hastalık kronikleşebilir ve solunum yetmezliğine ilerleyebilir. Hastalıkla ilgili farkındalığı artırmak için bu olguyu sunmaya amaçladık.

Anahtar Sözcükler: Interstisyel Akciğer Hastalığı, aripiprazol, interstisyel pnömoni, steroid tedavi.
Department of Immunology and Allergy Disease, Kırıkkale University Faculty of Medicine, Kırıkkale, Turkey
Kırıkkale Üniversitesi Tıp Fakültesi, İmmunoloji ve Allerii Hastalıkları, Kırıkkale

Submitted (Başvuru tarihi): 30.04.2021 Accepted (Kabul tarihi): 05.10.2021

Correspondence (iletişim): Gulistan Alpagat, Department of Immunology and Allergy Disease, Kırıkkale University Faculty of Medicine, Kırikkale, Turkey

e-mail: gulistanalpagat16@gmail.com

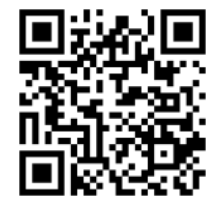


Interstitial lung disease (ILD) is a heterogeneous group of diseases, the etiology of which can be influenced by many factors. It is accepted that $2-3 \%$ of ILDs are due to drugs, and ILDs account for $70 \%$ of drug-induced lung diseases (1). We present here a case that developed non-specific interstitial pneumonia (NSIP) after the regular use of aripiprazole for bipolar disorder.

\section{CASE}

A 51 -year-old female patient was referred to the respiratory outpatient clinic with severe asthma, and complaints of dry cough and shortness of breath for about 2 years. The symptoms were of moderate severity, preventing such strenuous activities as exercise. She had been under treatment with high dose inhaled corticosteroid (ICS) and long-acting beta2-agonists (LABA) (salmeterol+fluticasone $50 \mathrm{mg} / 500 \mathrm{mg} /$ day), montelukast-sodium (10 mg/day) and tiotropium (18 mcg/day), however her symptoms in recent months had been unresponsive. She had been taking aripiprazole for bipolar disorder for 3 years and levothyroxine for Hashimoto's thyroiditis. The patient was an active smoker with 10 pack/years, but no alcohol or other substance use disorders. She had no recent travel history, pet ownership, occupational exposure or tuberculosis history. A physical examination revealed bilateral crackles and digital clubbing. The respiratory rate was $16 / \mathrm{min}$, axillary temperature was $37^{\circ} \mathrm{C}$, heart rate was $80 / \mathrm{min}$, systemic blood pressure was $125 / 75 \mathrm{mmHg}$, oxygen (O2) and saturation at room air was $96 \%$. Other system examinations were normal.

In laboratory tests, serum C-reactive protein was 4.1 $\mathrm{mg} / \mathrm{L}$, erythrocyte sedimentation rate was $41 \mathrm{~mm} / \mathrm{h}$, white blood cell was $7,500 / \mathrm{mm} 3$, hemoglobin was $11.2 \mathrm{~g} / \mathrm{dL}$ and platelet count was $211,000 / \mathrm{mm} 3$. Serum autoimmune panel (ACE, ANA, anti-dsDNA, c-ANCA, pANCA, AMA, ASMA, anti-CCP, RF, ASA, anti-Ro, anti-LA) resulted normal twice. Resting blood tests, including glucose, hepatic markers, renal and hepatic function tests were also within the normal range.

Chest X-ray showed bilateral non-homogeneous infiltrations in the middle-low lung areas (Figure 1). High resolution computed tomography (HRCT) revealed mediastinal retrocaval lymphadenopathy (LAP) $(18 \times 11 \mathrm{~mm})$, mosaic pattern, peripheral reticular density and patchy ground-glass opacities in the bilateral lower lung parenchyma with peribronchial thickening (Figure 2). Sputum acid-fast bacilli (ARB) samples resulted negative three times, as well as a sputum mycobacterium culture. In pulmonary function tests (PFT), a restrictive pattern with
FEV1 $33 \%$ (0.92L), FVC as $36 \%$ and FEV1/FVC $98 \%$ was noted. The increase in FEVI reversibility was lower than $10 \%$ and $100 \mathrm{~mL}$. A diffusion lung test with carbonmonoxide (DLCO) was 50\% and DLCO/VA was $110 \%$. Cardiac failure was ruled out by a cardiologic consultation, normal echocardiography (ECHO) and a normal serum pro-brain natriuretic peptide (pro-BNP). To diagnose ILD, a fiber optic bronchoscopy (FOB) was performed, and no endobronchial lesion was observed. A bronchoalveolar lavage (BAL) analysis showed a normal cellular profile with a negativity of culture. Diagnostic video-assisted thoracic surgery (VATS) was performed to specify interstitial pneumonitis. A lung biopsy report identified "hypertrophy of smooth muscles in terminal bronchial structures, increase in the distance of the alveolar ductus, subpleural and alveolar septal thickening, increased vascular wall thickness, mononuclear inflammatory cell infiltration, including scattered lymphocytes and plasmocytes in the interstitial area with lymphoid aggregates patches, mild to moderate interstitial inflammation, and relatively homogeneous interstitial fibrosis". Histochemical staining revealed staining in favor of connective tissue in the focal areas (Figure 3).

A diagnosis of NSIP was made because of restriction in PFT, decrease in DLCO, and histopathological findings of lung biopsy in accordance with radiological findings and clinical correlation. The possible etiologies of infection, aspiration, cardiac failure, pet ownership and negativity in the serum auto-immune panel were excluded. Collagen tissue diseases such as rheumatoid arthritis or scleroderma were absent, based on negative autoimmune blood markers, and rheumatologic consultation. The most common indicators of ILD were absent in the patient's history, including long-term exposure to such hazardous inhaled materials as asbestos. Considering that the onset of symptoms occurred during aripiprazole use with an indication of bipolar disease, drug-related lung disease was considered.

Aripiprazol was discontinued as a suspicious drug, and an alternative treatment was suggested by psychiatry. For the treatment of NSIP, oral corticosteroid (OCS) was initialed at $0.5 \mathrm{mg} / \mathrm{kg}$ with prophylaxis of gastritis and pneumocystis carinii, given the presence of severe dyspnea and low PFT values. An ICS-LABA combination was continued for its steroid-sparing effect. After 2 weeks, the OCS dose was reduced to $16 \mathrm{mg}$, and discontinued after 11 months through slow tapering. During follow-up, clinical complaints decreased, PFT values increased 
(FEV1 as $47 \%-1.30 \mathrm{~L}, \mathrm{FVC}$ as $40 \%, \mathrm{FEVI} / \mathrm{FVC}$ as $123 \%$ ), and radiologic improvement was noted.

The patient has been under follow-up for 5 years, and has had four NSIP flares with hospitalization. She has used OCS seven times in 5 years. Even though aripiprazol was discontinued, a mild progression in $\mathrm{FEV} 1$ as $35 \%$ (0.96L), FVC as $32 \%$ and FEV1/FVC as $119 \%$ was seen, in contrast to the severe radiologic progression (Figure 4 and 5). Her dyspnea and cough became persistent, and she was prescribed long-term oxygen treatment. Radiological images of the patient are presented in Figure 6 from before the start of OCS treatment, 6 months after starting and during the 5 -year follow-up. The patient has not developed coronavirus disease.

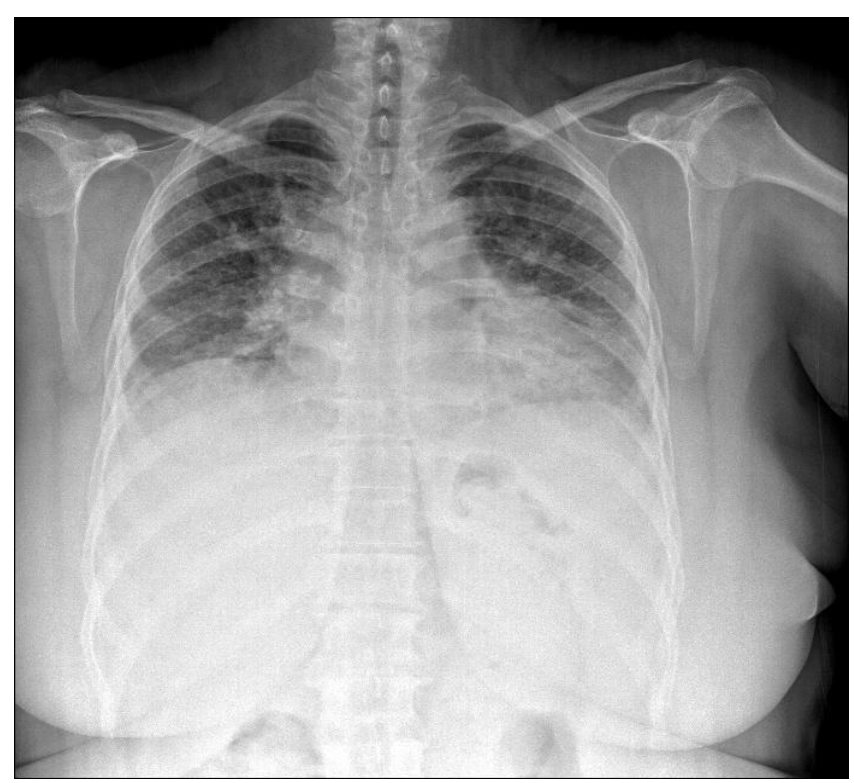

Figure 1: Bilateral non-homogeneous infiltrations in the middle-low lung areas (First $X$-ray)

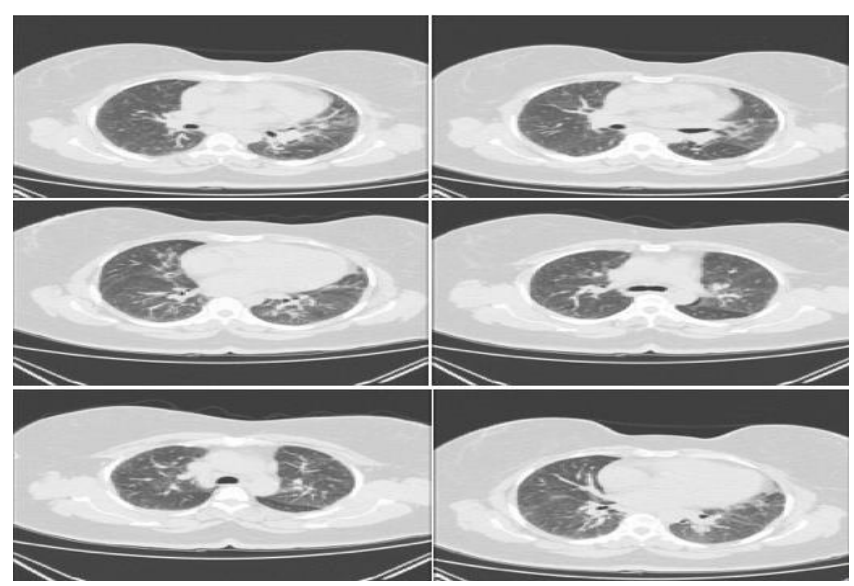

Figure 2: Mediastinal retrocaval lymphadenopathy (LAP) $(18 \times 17 \mathrm{~mm})$, mosaic pattern in lung parenchyma, bilateral-peripheral reticular density and peripheral patchy ground-glass opacities in the lower lung lobes with peribronchial thickening (thorax high-resolution computed tomography (HRCT))

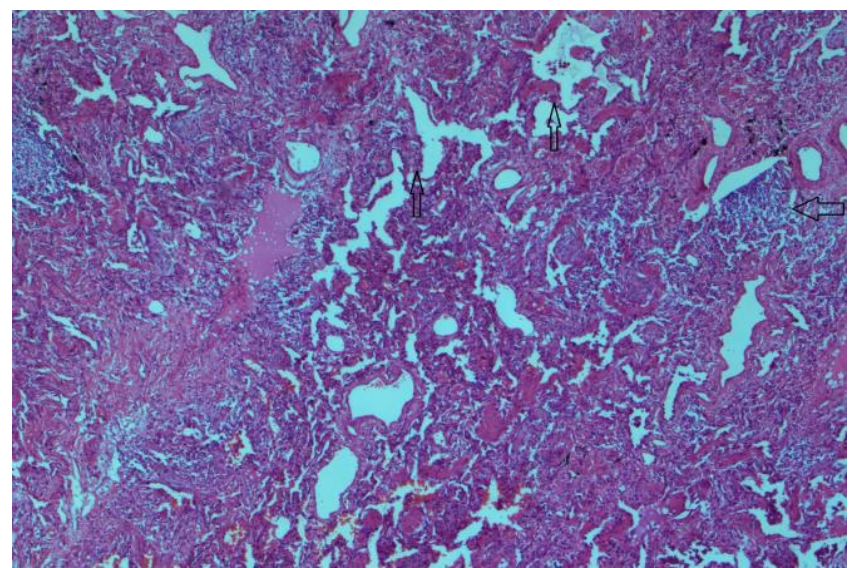

Figure 3: Thick arrow: lymphoid aggregate, Thin arrow: alveolar septal thickening (Hematoxilen \& eosin X40)

\section{DISCUSSION}

NSIP occurs with the uniform enlargement of the alveolar septa along with fibrosis and inflammation (2). It affects men and women equally, and the average age of onset is 48. Shortness of breath and dry cough are the most common patient complaints, and a combination of ground-glass opacities, consolidation and irregular lines showing subpleural peripheral distribution are common radiological findings. Although these findings are characteristic, atypical UIP cases may have a similar appearance. The average life expectancy varies between 1.3 and 15 years (3). NSIP may be idiopathic or may develop as a complication of connective tissue disease, hypersensitivity pneumonia, drug-induced interstitial lung disease and diffuse alveolar injury (4).

This was a rare case of NSIP development due to aripiprazole - an atypical anti-psychotic agent that has been widely used for the management of schizophrenia and bipolar diseases. Its mechanism of action includes partial agonistic activity at the dopamine-D2, and serotonin 5$\mathrm{HTIA}$ receptors, and antagonistic activity at the 5-HT2A receptors (5). Even though the drug is generally welltolerated, it has some common adverse events, such as extrapyramidal symptoms and weight gain. Its best known pulmonary effect is non-cardiogenic pulmonary edema, which can be diagnosed based on its acute setting and typical ECHO findings. Pulmonary edema was ruled out in our patient based on a normal ECHO and normal pro$\mathrm{BNP}$, and the absence of bilateral central ground-glass opacities in the pulmonary parenchyma.

ILD due to aripiprazole is a rare finding, with only one case reported in literature (6) - being a 36-year-old woman who developed respiratory symptoms after beginning aripiprazole treatment. Drug-related ILD (DI-ILD), however, was only diagnosed 4 years later, compared to 
3 years in our patient. In our case, the time until the onset of respiratory symptoms after aripiprazole was not clear, although the temporal relationship between drug commencement and the development of respiratory symptoms supported the etiologic relationship after the elimination of other reasons. The specific diagnosis of hypersensitivity pneumonitis in the reported case was based on the characteristic findings of ground-glass appearance on HRCT scan with the lymphocytic predominance in the BAL sample. The previous case report's radiology was also compatible with hypersensitivity pneumonitis, with bilateral multifocal mosaic pattern and ground-glass attenuation. Although the radiologic findings of the two patients were similar, indicating hypersensitivity pneumonitis, NSIP, as a subgroup of ILD, was diagnosed in our patient due to the chronic inflammation pattern on histopathology, and no lymphocytic predominance in BAL.

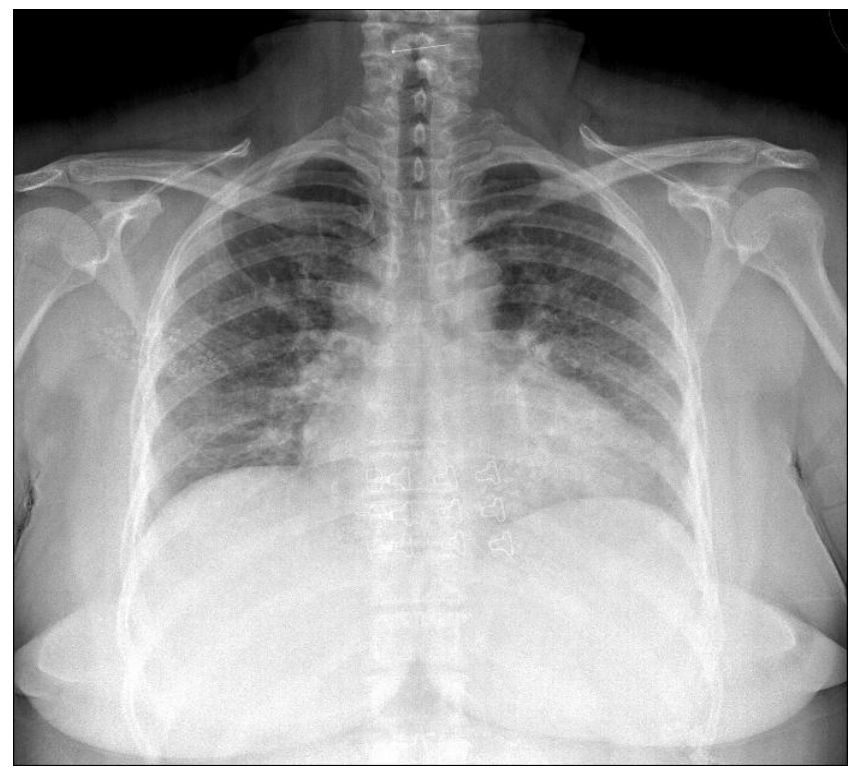

Figure 4: Peripheral and sub-rough reticular in zone opacities, heterogeneous density increase. (Last $X$-ray)

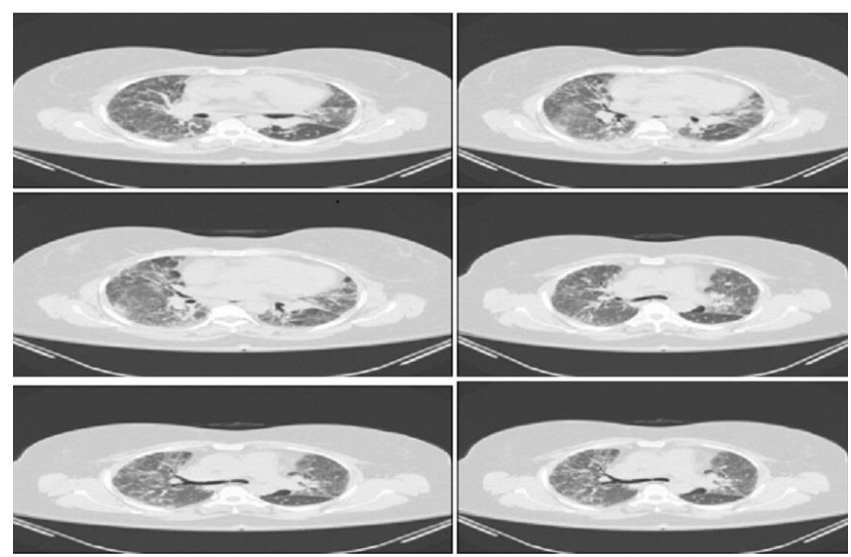

Figure 5: Irregularly limited and heterogeneous density increases in the lower bilateral zones, ground-glass appearance and septal thickening progression (last HRCT)
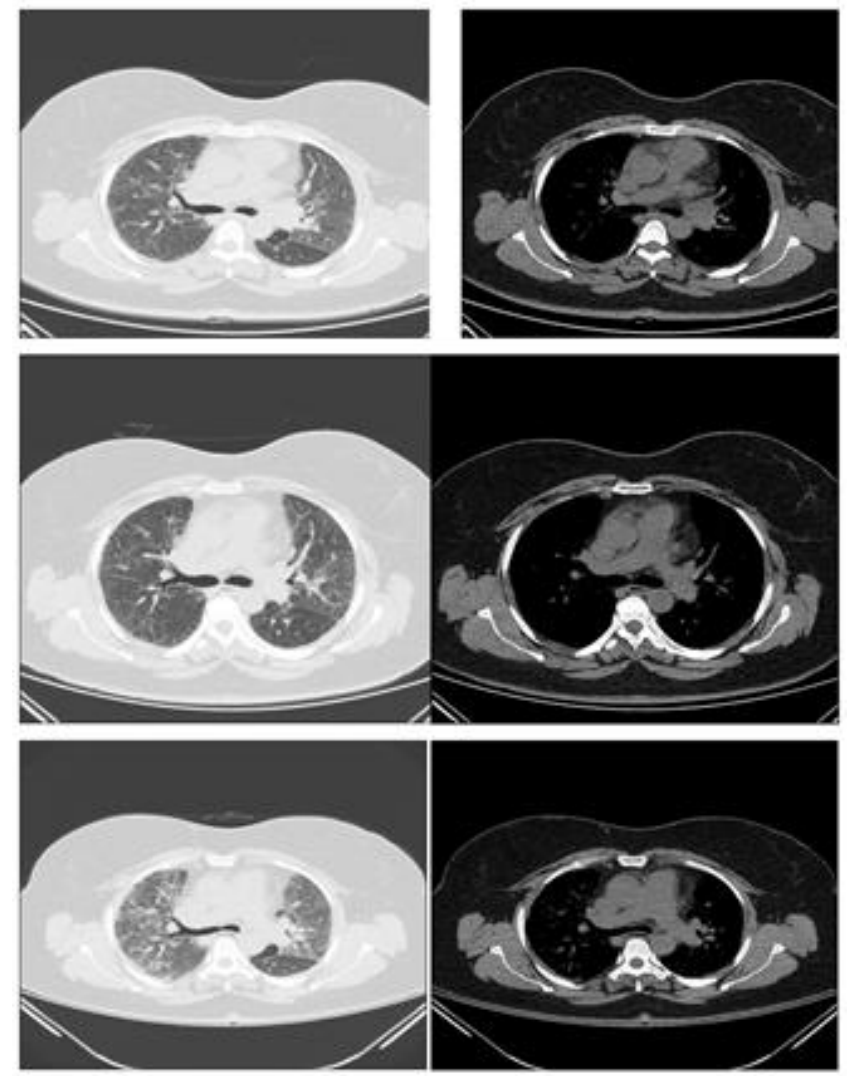

Figure 6: Radiological images from before the start of OCS treatment, 6 months after starting and during the 5-year follow-up (in order of top to bottom)

DI-ILD diagnoses are based on the compatibility of laboratory and imaging data in clinically compatible patients, based on an evaluation of the physical examination, laboratory and radiological findings together. The laboratory analysis is required to exclude infectious diseases, and autoimmune or rheumatological diseases. While some anti-infective and immunomodulatory drugs are known to cause lung damage, infections can be ruled out through culture studies in bronchoalveolar lavage (BAL) examination. PFTs with increased FEVI/FVC and decreased FVC and DLCO can help in the identification of a restrictive or obstructive model, although these results may overlap with other ILDs. HRCT is the most sensitive radiological examination for the diagnosis of ILDs (79).

Biopsy is not routinely recommended for diagnosis. Histological examination shows great similarity in idiopathic and drug-related forms. Transbronchial biopsy with FOB may be helpful in ruling out other ILDs, such as sarcoidosis (10). In NSIP, lung biopsies shows interstitial pneumonia, fibrosis or bronchiolitis obliterans, and findings suggestive of eosinophilic or extrinsic allergic alveolitis can be observed in some forms of DI-ILD $(11,12)$. 
ILD represents a heterogeneous group of pathologies that may be related to different causes. A low percentage of these lung diseases may be secondary to the administration of drugs or substances. Drug-Induced Interstitial Lung Diseases (DI-ILDs) have been associated with the administration of drugs such as anti-inflammatory and immunomodulators drugs, chemotherapeutics and cardiovascular drugs (13-15). Diagnostic doubt can be resolved through an analysis of the possible cause-effect relationship between the onset of a pulmonary pathology and exposure to a drug, and it is thus necessary to evaluate any recent pharmacological anamnesis and to investigate any previous ones (16). Toxic and immunological mechanisms have been held responsible for the development of DI-ILDs $(1,17)$. Various clinical pictures such as lung parenchymal disease, acute lung injury, pulmonary hemorrhage, malignancy, mediastinal, neuromuscular and pleural/pericardial pathologies can develop after drug use (18). The patient's clinic due to DI-ILDs may vary from mild to severe, and may sometimes be mortal (19). The National Cancer Institute common terminology criteria for adverse events suggest a grading system from mild (1) to fatal (5). At the time of diagnosis, our patient had grade 2 (moderate) dyspnea, being symptomatic, but not interfering with daily activities, and progressed to 3 (severe) as symptomatic with limitation in daily activities, as well as an oxygen need in 5 years. A DI-ILD prognosis may have a favorable outcome after drug withdrawal, although complete recovery is rare. A significant proportion of cases follow a progressive clinical course with mortality-related respiratory failure, and progression of the primary underlying disease (15). As in the reports of previous cases, our case saw a slow progression of lung disease over 5 years, and also her bipolar disease worsened, due possibly to recurrent OCS use and alternative medicines that were not as effective as aripiprazole.

In addition to drug discontinuation and supportive therapy, corticosteroids are useful in the treatment of ILD diseases. It is recommended that oral corticosteroids (OCS) be initiated at a dose of $0.5-1 \mathrm{mg} / \mathrm{kg} /$ day, continued for 2-6 months and gradually tapering the dose after clinical improvement is achieved. If the symptoms or radiologic findings recur during OCS dose reduction or interruption, the OCS dose should be increased again. Oxygen therapy and inhaled bronchodilator therapy are recommended as supportive therapies (20-23). In our case, after the discontinuation of aripiprazole and the administration of systemic corticosteroid therapy for almost a year, her symptoms, PFTs and radiological findings partially im- proved. Even though the radiologic and clinical improvement was more apparent in the previously reported case (6), our patient's clinical and radiologic stage was more severe, and permanent restrictive changes progressed in 5 years to respiratory failure.

There is a lack of information in literature charting the rate of improvement or decline in patients who did not develop fibrosis after the drug was stopped, and so studies involving large case series are needed.

The limitations of this case report include the lack of an exact initiation time of ILD, which was based on the patient's anamnesis, with the onset of respiratory symptoms after aripiprazole being reported by the patient. Another limitation is the diagnosis of ILD based on non-specific clinical and radiologic findings that could have occurred for other reasons that we were unable to identify.

\section{CONCLUSION}

The frequency and facilitating factors of DI-ILD are not fully known. The patient's medication history should be questioned in detail when investigating the etiology of ILD. In patients with respiratory symptoms that began after starting treatment with a specific drug, one should keep DI-ILD in mind. Initiating treatment without delay is very important for patient prognosis. As in our case, disease progression and the development of respiratory failure cannot be prevented in some patients, despite the currently available treatments. Although lung biopsy is recommended for diagnosis, when a biopsy cannot be performed for any reason, a diagnosis should be made based on clinical and radiological findings, the drug in question should be stopped immediately, and treatment with steroids and supportive drugs should be started.

\section{CONFLICTS OF INTEREST}

None declared.

\section{AUTHOR CONTRIBUTIONS}

Concept - G.A., A.B., S.A.Y., M.P., B.D., A.F.K.; Planning and Design - G.A., A.B., S.A.Y., M.P., B.D., A.F.K.; Supervision - G.A., A.B., S.A.Y., M.P., B.D., A.F.K.; Funding - A.B.; Materials - G.A.; Data Collection and/or Processing - G.A.; Analysis and/or Interpretation - A.F.K.; Literature Review - G.A.; Writing - G.A.; Critical Review A.B.

\section{YAZAR KATKILARI}

Fikir - G.A., A.B., S.A.Y., M.P., B.D., A.F.K.; Tasarım ve Dizayn - G.A., A.B., S.A.Y., M.P., B.D., A.F.K.; Denetle- 
me - G.A., A.B., S.A.Y., M.P., B.D., A.F.K.; Kaynaklar A.B.; Malzemeler - G.A.; Veri Toplama ve/veya İşleme G.A..; Analiz ve/veya Yorum - A.F.K.; Literatür Taraması G.A.; Yazıyı Yazan - G.A.; Eleştirel İnceleme - A.B.

\section{REFERENCES}

1. Schwaiblmair M, Behr W, Haeckel T, Märkl B, Foerg W, Berghaus T. Drug induced interstitial lung disease. Open Respir Med J 2012; 6:63-74. [CrossRef]

2. Katzenstein AL, Fiorelli RF. Nonspecific interstitial pneumonia/ fibrosis. Histologic features and clinical significance. Am J Surg Pathol 1994; 18:136-47. [CrossRef]

3. Raghu G, Remy-Jardin M, Myers JL, Richeldi L, Ryerson CJ, Lederer DJ, et al. American Thoracic Society, European Respiratory Society, Japanese Respiratory Society, and Latin American Thoracic Society. Diagnosis of Idiopathic Pulmonary Fibrosis. An Official ATS/ERS/JRS/ALAT Clinical Practice Guideline. Am J Respir Crit Care Med 2018; 198: e44-e68.) [CrossRef]

4. Myers JL. Reprint of: Nonspecific interstitial pneumonia: Pathologic features and clinical implications. Semin Diagn Pathol 2018; 35:334-8. [CrossRef]

5. Croxtall JD. Aripiprazole: a review of its use in the management of schizophrenia in adults. CNS Drugs 2012; 26:155-83. [CrossRef]

6. Gunasekaran K, Murthi S, Jennings J, Lone N. Aripiprazole-induced hypersensitivity pneumonitis. BMJ Case Rep 2017; 2017: bcr2017-219929. [CrossRef]

7. Ben-Noun L. Drug-induced respiratory disorders: incidence, prevention and management. Drug Saf. 2000; 23:143-64. [CrossRef]

8. Janz DR, O'Neal HR Jr, Ely EW. Acute eosinophilic pneumonia: A case report and review of the literature. Crit Care Med 2009; 37:1470-4. [CrossRef]

9. American Thoracic Society/European Respiratory Society International Multidisciplinary Consensus Classification of the Idiopathic Interstitial Pneumonias. Am J Respir Cri. Care Med 2002; 165:277. 304. [CrossRef]

10. Romagnoli M, Bigliazzi C, Casoni G, Chilosi M, Carloni A, Dubini A, et al. The role of transbronchial lung biopsy for the diagnosis of diffuse druginduced lung disease: a case series of 44 patients. Sarcoidosis Vasc Diffuse Lung Dis 2008; 25:36-45.

11. Topcu F, Akyildiz L. Lung diseases due to nonchemotherapeutic drugs. In: Ozlu T, Metintas M, Karadag $M$, Kaya $A$, eds. Respiratory system and diseases basic reference book Vol 2. Istanbul: Istanbul Medical Bookstore; 2010: 2505-30.
12. Ulubas B, Sahin G, Ozer C, Aydin O, Ozgür E, Apaydin D. Bronchiolitis obliterans organizing pneumonia associated with sulfasalazine in a patient with rheumatoid arthritis. Clin Rheumatol 2004; 23:249-51. [CrossRef]

13. Cleverley JR, Screaton NJ, Hiorns MP, Flint JD, Müller NL. Drug-induced lung disease: highresolution CT and histological findings. Clin Radiol 2002; 57:292-9. [CrossRef]

14. Lateef $O$, Shakoor N, Balk RA. Methotrexate pulmonary toxicity. Expert Opin Drug Saf 2005; 4:723-30. [CrossRef]

15. Distefano G, Fanzone L, Palermo M, Tiralongo F, Cosentino $S$, Inì $C$, et al. HRCT patterns of druginduced interstitial lung diseases: a review. Diagnostics (Basel) 2020; 10:244. [CrossRef]

16. Dweik RA. Drug-induced pulmonary disease. In: Baum GL, Crapo JD, Celli BR, Karlinsky JB (eds). Textbook of Pulmonary Diseases, 6th; Lippincott Raven: Philadelphia, PA, USA, 1988: 477-90.

17. Matsuno $\bigcirc$. Drug-induced interstitial lung disease: mechanisms and best diagnostic approaches. Respir Res 2012; 13:39. [CrossRef]

18. Thomeer MJ, Costabe U, Rizzato G, Poletti V, Demedts $M$. Comparison of registries of interstitial lung diseases in three European countries. Eur Respir J Suppl 2001; 32:114s-118s.

19. Pirmohamed M, James S, Meakin S, Green C, Scott AK, Walley TJ, et al. Adverse drug reactions as cause of admission to hospital: prospective analysis of 18820 patients. BMJ 2004; 329:15-9. [CrossRef]

20. Turker H. Diffuse parenchymal lung diseases due to drugs. In: Tabak L, Kumbasar $\bigcirc \bigcirc$ (eds). Diffuse Parenchymal Lung Diseases. Thorax Books. 2013; 17: 283-94

21. Raissy HH. Harkins M. Marshik PL. Drug- induced pulmonary disease. In: Dipiro JT. Talbert RL. Yee GC, et al. Pharmacotherapy: A Pathophysiologic Approach.7th ed. New York: Mcgraw-Hill; 2008:521-34.

22. Costabel U. Radiation and drug induced pneumopathies. Rev Port Pneumol 2000; 4:141-4. [CrossRef]

23. Senyigit A. Drug-related interstitial lung diseases. Current Chest Diseases Series 2014; 2: 394-401. [CrossRef] 